\title{
Nuclear DNA variation in the genus Allium L. (Liliaceae)
}

\author{
R. M. Labani and \\ T. T. Elkington
}

Department of Botany, The University, Sheffield S10 2TN, U.K.

4C nuclear DNA contents were determined for 42 Allium species, selected from all major taxonomic sections in the genus. Estimates of nuclear volumes were also made. A range of 4 C DNA values from $41 \cdot 19 \mathrm{pg}$ to $142.78 \mathrm{pg}$ was found, largely unrelated to basic chromosome number, polyploidy or taxonomic group, but correlated with flowering time. The results are discussed in relation to distribution of DNA values in the genus, proportions of chromosome C-banding, breeding systems and climatic adaptation.

\section{INTRODUCTION}

The genus Allium has been studied cytologically over many years, commencing with the studies of Levan $(1931,1932,1933,1935,1936)$. The c. 400 perennial species encompass considerable morphological variation and have been divided into a number of subgenera and sections (see Vvedenskii, 1935; Stearn, 1978, 1980; Wendelbo, 1969 , 1971) distributed, mainly in temperate regions of Europe, North Africa, Asia and North America, and with outlying species in Ceylon and South Africa (Stearn, 1978). The genus includes series of basic chromosome numbers from $x=7$ to $x=10$ and a number of polyploids. Previous determinations of nuclear DNA in Allium species have been made by several authors (see table 3 ). In common with a range of other Angiosperm genera (see Bennett and Smith, 1976; Bennett, Smith and Heslop-Harrison, 1982) these results indicate that there is substantial interspecific variation in DNA amounts within Allium, but they only cover a total of 32 taxa in the genus. On the basis of the results of Jones and Rees (1968) for 25 taxa Narayan (1983) has suggested that, in common with several other genera viz Clarkia, Nicotiana and Lathyrus, the nuclear DNA amounts of Allium species are dicontinuously distributed, species forming groups in this respect, between which there are regular increases in DNA amounts. The small sample of species in Allium for which DNA determinations are so far available make it difficult to comment adequately on any possible quantitative relationships between species, with taxonomic groupings or indeed on other aspects of the genus' biology. We have therefore, as part of a larger study on variation of the genus Allium, determined nuclear DNA values for 42 specieschosen to include representatives of all the major morphological groups in the genus.

\section{MATERIALS AND METHODS}

\section{Materials}

Roots were obtained from seedlings or bulbs obtained from a variety of sources (table 1). Identifications of the majority of accessions were checked by reference to appropriate keys and reference material in the British Museum (Natural History). Seeds of $A$. cepa var. Ailsa Craig were grown on filter paper at the same time and used as a standard.

\section{Methods}

Root tips were collected from the samples and $A$. cepa at the same time, fixed directly in $3: 1$ alcohol acetic acid and stored overnight. Fixed root tips were washed in distilled water and hydrolysed in $1 \mathrm{~N} \mathrm{HCl}$ at $60^{\circ} \mathrm{C}$ for 10 minutes; they were then stained in leuco-basic fuchsin for 2 hours at room temperature, washed in running tap water and placed in distilled water. Squash preparations were 
Table 1 Origins of Allium species used with initial flowering time and self compatibility type

\begin{tabular}{llll}
\hline & & Initial & \\
Subgenera and Sections & Taxon & month of & Compatibility \\
flowering & type* & Source \\
\hline
\end{tabular}

Subgenus Rhizirideum Section Rhizirideum

Section Schoenoprasum

Section Cepa

Section Anguinum

Subgenus Allium

Section Molium

Section Briseis

Section Ophioscorodon

Section Scorodon

Section Codonoprasum

Section Allium

Subgenus Melanocrommyum Section Melanocrommyum
A. cernuum Roth.

A. angulosum $\mathrm{L}$.

A. barsczewskii Lipsky

A. farreri Stearn

A. mairei H. Lev.

A. ochroleucum W. et Kit.

A. obliquum $\mathrm{L}$.

A. saxatile Bieb.

A. schoenoprasum L.

A. lineare $\mathrm{L}$.

A. cepa L. cv. Ailsa Craig

A. altaicum Pall.

A. fistulosum L.

A. galanthum Kar. and $\mathrm{Kir}$.

A. pskemense B. Fedtsch.

A. roylei Stearn

A. victorialis $\mathrm{L}$.

$\begin{array}{ll}\text { June } & \text { i } \\ \text { August } & \mathrm{c} \\ \text { August } & - \\ \text { May } & \mathrm{c} \\ \text { August } & \mathrm{c} \\ \text { August } & \mathrm{i} \\ \text { July } & \mathrm{c} \\ \text { July } & \mathrm{c} \\ \text { July } & \mathrm{c} \\ \text { June } & \mathrm{c} \\ \text { June } & \mathrm{c} \\ \text { July } & - \\ \text { July } & \mathrm{c} \\ \text { August } & \mathrm{c} \\ \text { July } & - \\ \text { July } & - \\ \text { July } & -\end{array}$

A. geyeri Wats.

A. moly L.

A. oreophilum C. A. Meyer DC.

A. trifoliatum C.yr

A. wallichii Kunth.

A. triquetrum L.

A. ursinum $\mathrm{L}$.

A. parciflorum Viv.

\section{A. flavum L.}
A. heldreichii Boiss.
A. sphaerocephalon $\mathrm{L}$.
A. ampeloprasum $\mathrm{L}$. A. porrum L. cv.
Musselburgh

A. scorzonerifolium Desf. ex

A. carinatum subsp. pulchellum Bonnier and Layens

A. carinatum L. subsp. carinatum

A. oleraceum L.

June

June

June

June

May

May

May

April

July

July

July

July

July

May

August

August June

A. atropurpureum Waldst. and June Kit.

A. aflatunense B. Fedtsch.

A. cristophii Trautv.

May

June

A. giganteum $\mathrm{Rgl}$.

July
Royal Horticultural Society (RHS) Gardens, Wisley, UK

Botanical Garden, Vacratot, Hungary RHS Gardens, Wisley UK

RHS Gardens, Wisley, UK. (ex Iran) Amsterdam, Free University Botanical Garden, Holland Copenhagen Botanical Garden, Denmark

Botanical Garden, Goteborg, Sweden Botanical Garden, Goteborg, Sweden University of Louis Pasteur, Strasbourg, France Botanical Garden, Karl Marx University, E. Germany

Suttons Seeds Ltd

Botanical Garden, Sheffield

University, UK

RHS Garden, Wisley, UK

Botanical Garden, Sheffield University, UK

R. Dadd

R. Dadd

Botanical Garden, Sheffield

University, UK

Royal Botanic Garden, Kew, UK

Van Tubergen, Holland

Van Tubergen, Holland

R. Dadd

R. Dadd

R. Dadd

Van Tubergen, Holland

Grindleford, Derbyshire, UK

Botanical Garden, Sheffield

University, UK

Botanical Garden, Copenhagen,

Denmark

Botanical Garden, Copenhagen,

Denmark

Botanical Garden, Copenhagen, Denmark

Botanical Garden, Copenhagen, Denmark

Royal Botanic Garden, Kew, UK Botanical Garden, Copenhagen,

Denmark

Royal Botanic Garden, Kew, UK Suttons Seeds Ltd

Van Tubergen, Holland

Van Tubergen, Holland

Van Tubergen, Holland

Van Tubergen, Holland 
Table 1 continued

\begin{tabular}{lllll}
\hline Subgenera and Sections & Taxon & $\begin{array}{l}\text { Initial } \\
\text { month of } \\
\text { flowering }\end{array}$ & $\begin{array}{l}\text { Compatibility } \\
\text { type* }\end{array}$ & Source \\
\hline & A. macleanii Baker & June & - & Van Tubergen, Holland \\
& $\begin{array}{ll}\text { A. stipitatum Rgl. } \\
\text { A. karataviense Rgl. }\end{array}$ & June & i & Van Tubergen, Holland \\
A. rosenbachianum Rgl. & June & i & Van Tubergen, Holland \\
A. schubertii Zucc. & June & c & Van Tubergen, Holland \\
\hline
\end{tabular}

* c, self compatible; i, incompatible (Data from Al-Sheikh Hussain, 1977; Badr, 1977; El-Gadi, 1976; El-Maghbub, 1982; Labani, 1984).

made in a drop of distilled water and made permanent by freezing in liquid carbon dioxide and mounting in Euparal. Measurements of DNA were made within two days using a Vickers M86 scanning microdensitometer at $\lambda_{\max }$ (approximately $570 \mathrm{~nm})$. Nuclei in early or mid-prophase (4C) were selected for scanning. Two readings of absorption were made on each nucleus and the background.

From these figures the nuclear DNA amounts for each sample was calculated using the formula:

$$
4 \mathrm{C} \text { nuclear DNA }=\frac{A}{B} \times C
$$

where $A=4 C$ nuclear DNA value of $A$. cepa var. Ailsa Craig i.e., $76.00 \mathrm{pg}$ from the determinations of Van't Hof (1965) and Bennet and Smith (1976). $B=$ mean absorption figure measured for the $A$. cepa sample. $C=$ mean of the absorption figures measured for the sample nucleus minus those of the background readings.

DNA values reported are means and standard errors of 10 nuclei per root tip for each of three root tips taken from a different seedling or bulb. The errors inherent in microdensitometry are discussed in detail by Bennett and Smith (1976) and D. J. Goldstein (1981).

Photographs were taken of interphase nuclei from each Allium species, using a Zeiss Ultraphot microscope with phase contrast optics. Prints were made at a final magnification of $\times 3500$. Nuclear volumes were determined using a Graphics tablet and Apple II micro-computer together with a program for computing volumes from readings of nuclear circumference; this assumed nuclei to be spherical, following Sparrow and Nauman (1974).

\section{RESULTS AND DISCUSSION}

\section{Nuclear DNA values}

The results (table 2) show that there is considerable variation in $4 \mathrm{C}$ nuclear DNA contents in the 42
Allium species for which determinations were made. Each DNA value represents a single sample of the species; a comparison with other published values (mostly also listed in Bennett and Smith 1976; Bennett, Smith and Heslop-Harrison, 1982) is given in table 3 . Some of the results show some similarity to previously published values but generally lie outside their 95 per cent confidence limits (table 3 ). Only in $A$. porrum is a previously published figure $(117.0 \mathrm{pg}$; Murin 1976) near to the 95 per cent confidence limit. The other previously published figure for this species $(48.2 \mathrm{pg}$; Ranjekar, Pallota and Lafontaine (1978)), is very discrepant. The high correlation between the nuclear DNA content and nuclear volume (fig. 3) determined in the present investigation supports strongly the value recorded here. It is therefore difficult to explain the difference unless Ranjekar et al. (1978) were wrong in their DNA determination or species identification. In A. schoenoprasum our value is almost double that recorded by Jones and Rees (1968) for the diploid A. sibiricum which Stearn (1978) includes within A. schoenoprasum.

In addition to the species listed in table 3 a $4 \mathrm{C}$ DNA value of $151.6 \mathrm{pg}$ is given for $A$. globosum Bieb. by Jones and Rees (1968); this value, the highest to be recorded in the genus, should be compared with the value of $44.59 \mathrm{pg}$ for $A$. saxatile determined here, since Stearn (1978) has shown A. globosum to be included within $A$. saxatile. Jones (personal communication) has stated that independent identifications of plants grown by Jones and Rees (1968) were not made, so this and some other values given by them may not be attributable to listed species.

\section{Distribution of nuclear DNA values}

Narayan (1983) has proposed that in Allium, as in several other genera, the distribution of DNA amounts between species is discontinuous with species group 2C DNA means at intervals of 


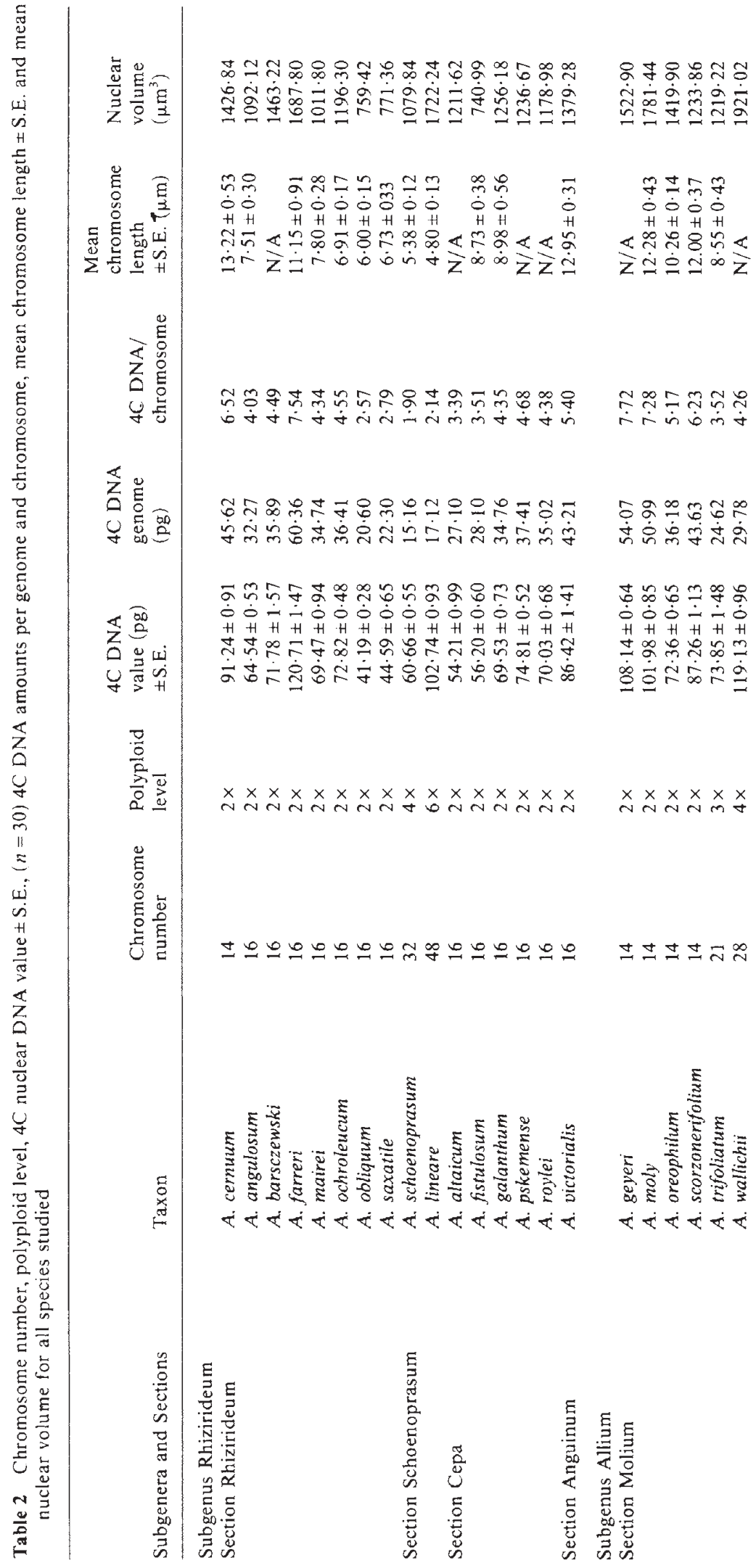




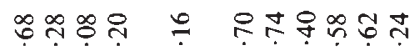

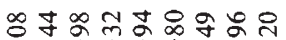

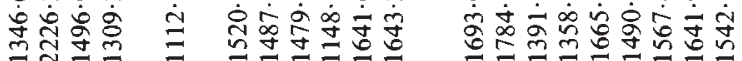

๙

$\dot{0} \dot{0} \dot{0} \dot{0} \quad \dot{0} \quad \dot{0} \dot{0} \dot{0} \dot{0} \dot{0} \dot{0}$

ชีย์

$\dot{\dot{d}} \dot{\sim} \dot{\sim}$

저유ำ

$\dot{\sigma} \dot{\sim} \dot{\alpha} \dot{\infty} \dot{0}$

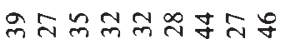

$\dot{0} \dot{0} \dot{0} \dot{0} \dot{0} \dot{0_{H}} \dot{0} \dot{0} \dot{0}$

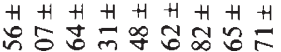

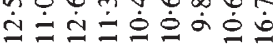

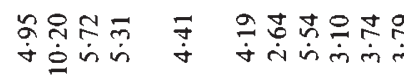

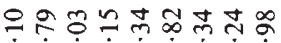
$\dot{r} \dot{r} \dot{\theta} \dot{r} \dot{\theta} \dot{n} \dot{0}$

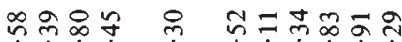

㠻守守

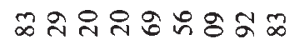
它

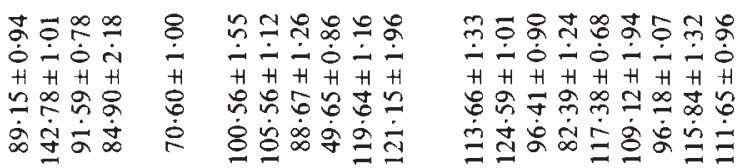

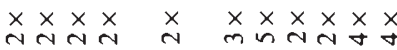

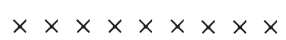

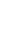

(n)

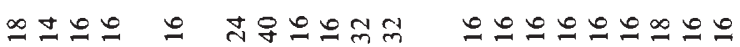
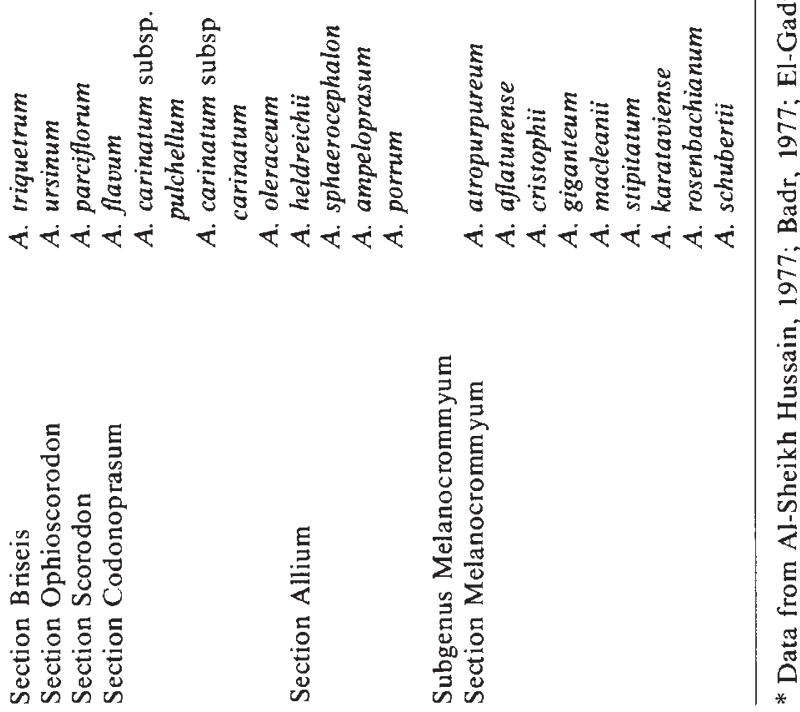
Table 3 Comparison between Allium nuclear DNA values determined and their $95 \%$ confidence limits and other published values

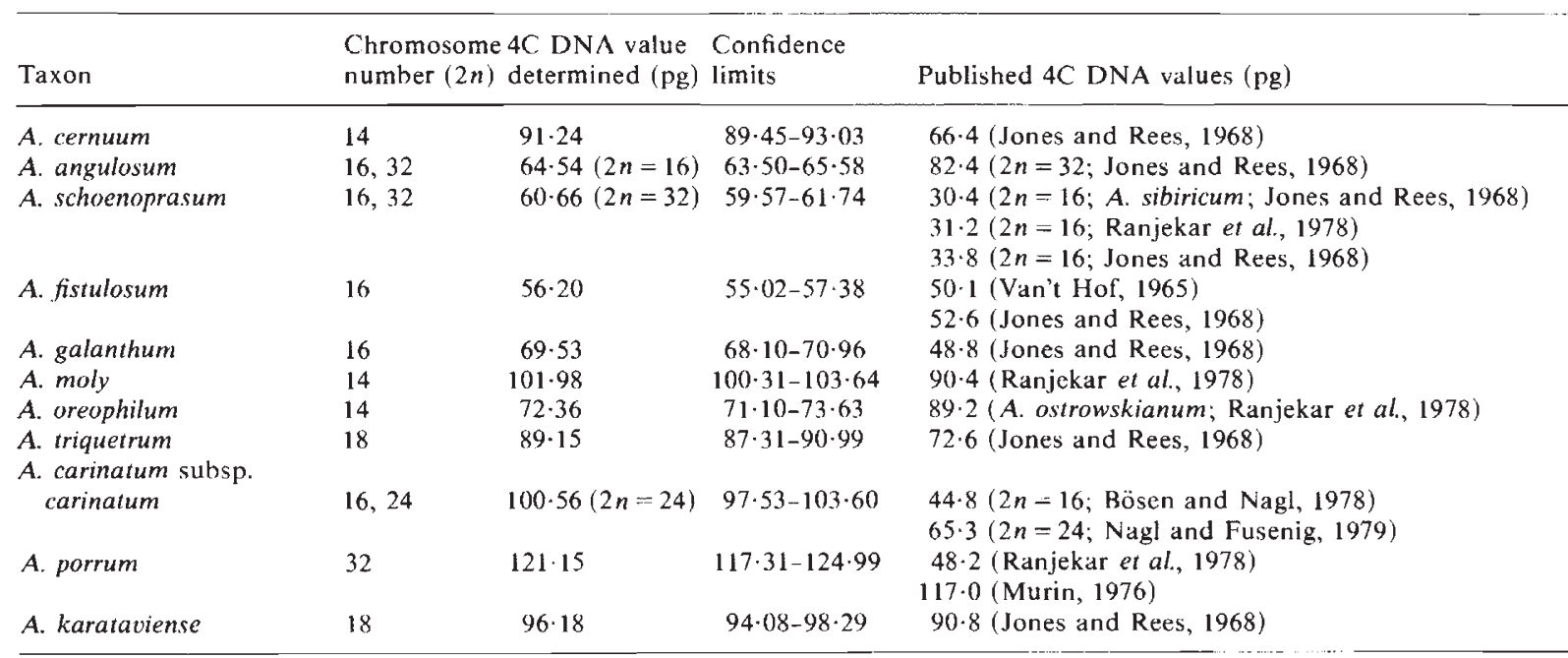

$4 \cdot 25 \mathrm{pg}$. Since his data were restricted to 25 taxa studied by Jones and Rees (1968) it was thought worth while to plot the distributions of the 75 DNA values available for the genus (see table 2; Bennett and Smith 1976; Ranjekar et al. 1978; Bennett, Smith and Heslop-Harrison, 1982). Figure 1 plots the distribution as DNA 4C values and shows that although some discontinuities exist, there are no regular groups with means separated at $8 \cdot 5 \mathrm{pg}$ and alternating discontinuities. Comparison of the values of Jones and Rees (1968) with subsequent determinations (fig. 1) shows that the apparent discontinuities recognised by Narayan (1983) are the result of inadequate sampling in this large genus. It is possible that some of the discontinuous DNA distributions suggested for other genera (Rees and Narayan, 1981; Narayan, 1982, 1983) may also result from a similar sampling error, particularly in Lathyrus where determinations of only 24 North temperate species are available from a world total of 130 species (Willis, 1966). DNA contents in relation to basic chromosome
number, polyploid levels and genomes

The species sampled vary in ploidy level from 2 to $6 \times$ and have basic chromosome members of $n=7,8$ and 9 (table 2 ). The $4 \mathrm{C}$ nuclear content per nucleus ranges from $41 \cdot 19 \mathrm{pg}$ in $A$. obliquum $(2 n=16)$ to $142.78 \mathrm{pg}$ in $A$. ursinum $(2 n=14)$ showing that there are significant differences in nuclear DNA content, amounting to a 4 fold variation, which are unrelated to ploidy level. Also there is no correlation between variation in basic number and DNA content; an analysis of variance of mean 4C DNA amounts of the species studied, grouped by base number $(x=7,8$ species; $x=8$, 32 species; $x=9,2$ species) shows that there is no significant variation (Table 4). These findings confirm those of Jones and Rees (1968).

4C. nuclear DNA values per genome have been calculated (table 2) and show a wide variation between species. In the closely related $A$. carinatum

Species samples

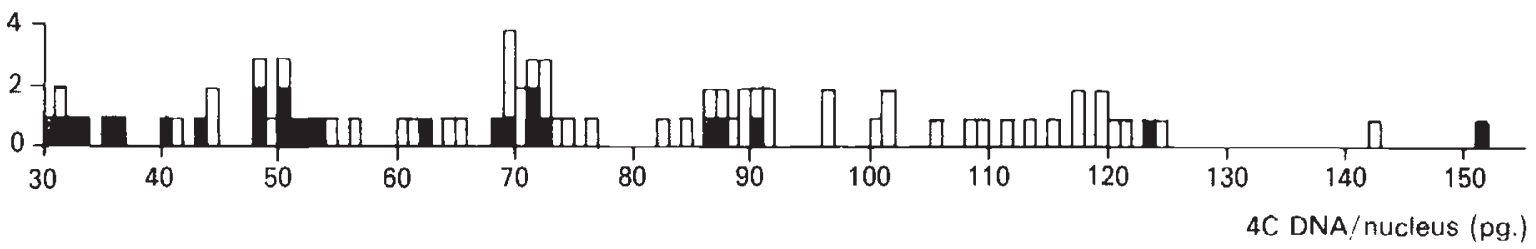

Figure 1 Histogram showing distribution of all Allium nuclear DNA values determined, published figures recalculated as $4 \mathrm{C}$ values where necessary; those of Jones and Rees (1968), as used by Narayan (1983) are shaded. 
subsp. carinatum (4C DNA/genome $33 \cdot 52 \mathrm{pg}$ ) and subsp. pulchellum (4C DNA/genome $35 \cdot 30 \mathrm{pg}$ ) the similar DNA amounts/genome suggest that $A$. carinatum subsp. carinatum is an autopolyploid based on $A$. carinatum subsp. pulchellum; this has previously been proposed on cytological grounds (Levan, 1937; Al-Sheikh-Hussain, 1977; Vosa, 1976). Constancy in DNA content/genome has also been shown in an autopolyploid series in Ranunculus ficaria (Smith and Bennett, 1975). In A. schoenoprasum the DNA content/genome in the tetraploid studied $(15 \cdot 16 \mathrm{pg})$ is consistent with the values for diploid samples determined by other authors (15.2-16.9 pg) (see table 3 ).

\section{DNA content and chromosome length}

There is a significant relationship (correlation coefficient $0.812 ; p<0.001 ; n=36$ ) between the mean $4 \mathrm{C}$ nuclear DNA value per chromosome and the mean chromosome length in the complement of all taxa studied (table 2, fig. 2). This indicates that DNA amount increases proportionately with increasing mean chromosome length and that the amount of DNA per unit chromosome length in Allium species remains uniform. A similar relationship has been shown by Nagl and Ehrendorfer (1974) in the Anthemideae (Asteraceae) and in Allium between DNA content and chromosome volume (Jones and Rees, 1968).

\section{DNA content and Nuclear Volume}

Mean nuclear volumes have been estimated for all taxa, for which DNA determinations were made (table 2). These results show that there is a significant variation in nuclear volume between the Allium species studied, with a range of $741.0 \mu \mathrm{m}^{3}$ for $A$. fistulosum $(2 n=16)$ to $2226 \cdot 3 \mu \mathrm{m}^{3}$ for $A$. ursinum $(2 n=14)$; there is a close association (correlation coefficient $0.814 ; p<0.001 ; n=42$ ) between the amount of DNA per nucleus and its volume (fig. 3), indicating that the DNA concentration per unit volume is constant in all Allium species studied. This relationship was first proposed by Sparrow and Miksche (1961) and Van't Hof and Sparrow (1963) and has been confirmed in a range of angiosperms e.g., Phaseolus (Ayonadhu, 1974), Lathyrus, Vicia (Rees, Cameron, Hazarika and Jones 1966), Anthemideae (Nagl and Ehrendorfer, 1974) and Gramineae (Sparrow and Nauman, 1974). In Eu-Sorghums, however, Paroda and Rees (1971) reported a significantly different correlation in this respect between the wild and cultivated species, indicating that there is a sharp distinction between these two species groups in terms of DNA density.

\section{DNA content and C-banding}

It has been shown (cf. Flavell, 1982) that much increase in DNA is due to sequence amplification. An association between highly repetitive sequences and heterochromatin has been demonstrated in both animals (John and Miklos, 1979) and plants (Appels, Driscoll and Peacock, 1978; Bedbrook et al., 1980; Deumling and Greilhuher, 1982). Furthermore positive correlations between the percentage of C-banded heterochromatin in the karyotype and DNA content have now been shown for a

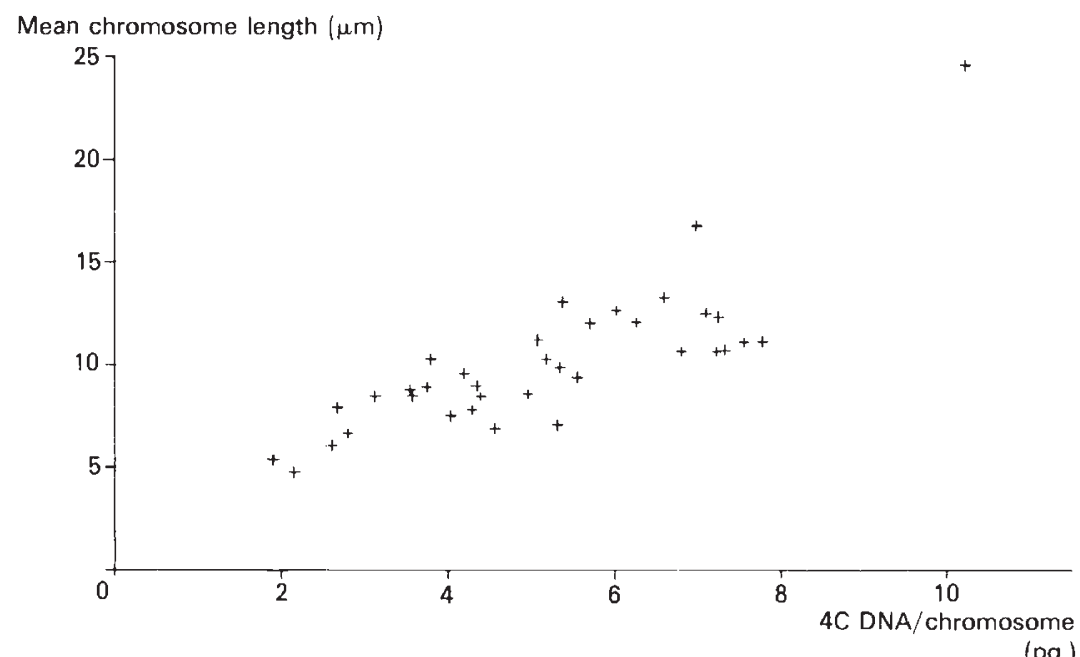

Figure 2 Relation of mean 4C DNA values per chromosome for all Allium species studied and the mean chromosome lengths, obtained from mitotic metaphase root tip cells, pretreated with $0.05 \%$ colchicine for 4 hours and stained with leuco-basic fuchsin. 


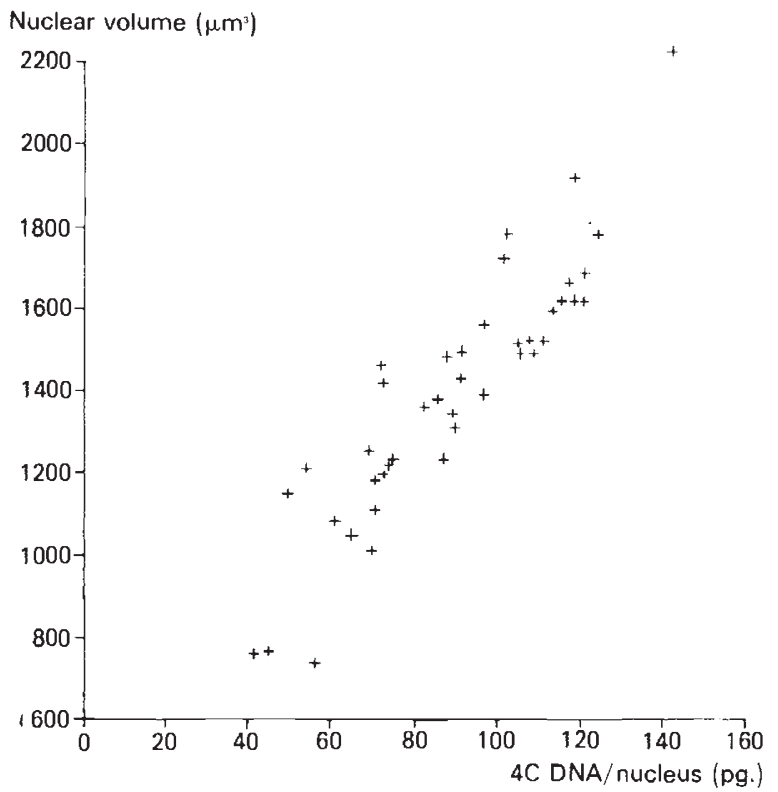

Figure 3 Relation of mean 4C DNA values per nucleus and mean nuclear volumes of interphase cells determined from 30 nuclei

range of flowering plants including Lolium (Thomas, 1981), Secale (Bennett, Gustafson and Smith, 1977), Gibasis karwinskyana (Kenton, 1983) and Zea mays (Rayburn, Price, Smith and Gold, 1985). In Allium, however, there is no correlation between increase in DNA nuclear content and proportion of C-banded material in the karyotype. Indeed $A$. ursinum with the largest DNA content $(71.39 \mathrm{pg} 4 \mathrm{C} \mathrm{DNA} /$ genome) has one of the lowest proportions of C-banded chromosome material in the genus $(0.4$ per cent) (Labani, 1984), while Allium species with the highest proportions, in section Codonoprasum (Vosa, 1976; Al-SheikhHussain, 1977), have 10-30 per cent of C-banded material, but only moderate DNA amounts $(21 \cdot 11$ $42 \cdot 454 \mathrm{C} \mathrm{DNA} /$ genome). If therefore there is any relationship between nuclear DNA and repetitive DNA it would appear to be unrelated to the proportion of C-banded heterochromatin.

Table 4 Analysis of variance of species 4C. DNA amounts partitioned by basic chromosome number

\begin{tabular}{|c|c|c|c|c|}
\hline $\begin{array}{l}\text { ANOVA } \\
\text { source }\end{array}$ & $\mathrm{df}$ & S.S. & M.S. & $\mathrm{F}$ \\
\hline mber & 2 & $1148 \cdot 6$ & $574 \cdot 3$ & $0.95(P>0.05)$ \\
\hline Residual & 39 & $23484 \cdot 9$ & $4602 \cdot 2$ & \\
\hline
\end{tabular}

\section{DNA content and taxonomic groups}

To investigate possible correlations between taxonomic groups and DNA nuclear content in Allium an analysis of variance (Table 5) was carried out on DNA amounts using subgenera to partition the between section variance according to the taxonomic classification of Stearn (1978) given in table 2 . The variance ratio is not significant showing that there is no correlation between DNA nuclear content and subgenera for this sample of species.

Table 5 Analysis of variance of mean sectional 4C DNA amounts partitioned by subgenera, according to the taxonomic classifications of Stearn (1978) (see table 2)

\begin{tabular}{|c|c|c|c|c|}
\hline $\begin{array}{l}\text { ANOVA } \\
\text { source }\end{array}$ & $\mathrm{df}$ & S.S. & M.S. & $\mathrm{F}$ \\
\hline Subgenus & 2 & $1294 \cdot 5$ & $647 \cdot 2$ & $3.649(P>0.05)$ \\
\hline Residual & 8 & $1419 \cdot 1$ & $177 \cdot 4$ & \\
\hline
\end{tabular}

\section{DNA content and breeding system}

Although there are no direct data on the breeding systems of the species studied, some data are available on self compatibility and incompatibility in some species studied (table 1). Comparison of DNA values for these species shows that selfcompatible species have lower DNA amounts, (4C mean of 18 species, $80.27 \mathrm{pg}$ ) than self-incompatible species ( $4 \mathrm{C}$ mean of 10 species $97.36 \mathrm{pg}$ ); but these differences are not significant (t-value 2.003; $\mathrm{df}=26 ; P>0.05)$. There is no evidence therefore of an association between nuclear DNA content and breeding system in Allium species. Differences in nuclear DNA content related to breeding system have been described in several other genera, some have outbreeding species with higher DNA contents i.e., Lathyrus (Rees and Hazarika, 1969; Rees and Jones, 1972) and Microseris (Price and Bachmann, 1975; Price, 1976) where the differences are also correlated with the perennial and annual habits of the out- and in-breeding species respectively; by contrast in Lolium outbreeding species have lower nuclear DNA contents than inbreeding species (Rees et al, 1966; Rees and Jones, 1967, 1972).

\section{DNA content and adaptation}

Recent explanations of variation in DNA content between species have often focussed on selective mechanisms. Thus Bennett (1972) and Smith and 
Bennett (1975) have suggested minimum generation time and life cycle type as being selective factors. More recently Grime and Mowforth (1982) and Grime (1983) have suggested that the nuclear DNA content of vascular plants has been subject to climatic selection, plants with large nuclear DNA contents being particularly characteristic of certain temperate zone geophytes and grasses in which early growth is achieved by expansion of large cells formed during warmer conditions in the previous autumn. In contrast fast-growing summer species, particularly colonising species, tend to have low DNA values/nucleus.

In Allium the species are distributed over a very wide area including Asia, North Africa, Europe and North America, the majority of species being found in temperate, mountain and mediterranean regions with well marked seasons, but with differing environmental conditions. It is possible therefore that DNA amounts in Allium may be related to environmental factors such as temperature, day length and humidity; some Allium species including almost all species in subgenus Melanocrommyum have originated from arid areas in Asia and North Africa, some e.g., many species in section Molium, grow in a Mediterranean climate, while other species have originated from more temperate regimes in Europe and North America. Although it has not been possible here to investigate any possible relationship between climatic adaptation and DNA amount, data are

Initial month of flowering

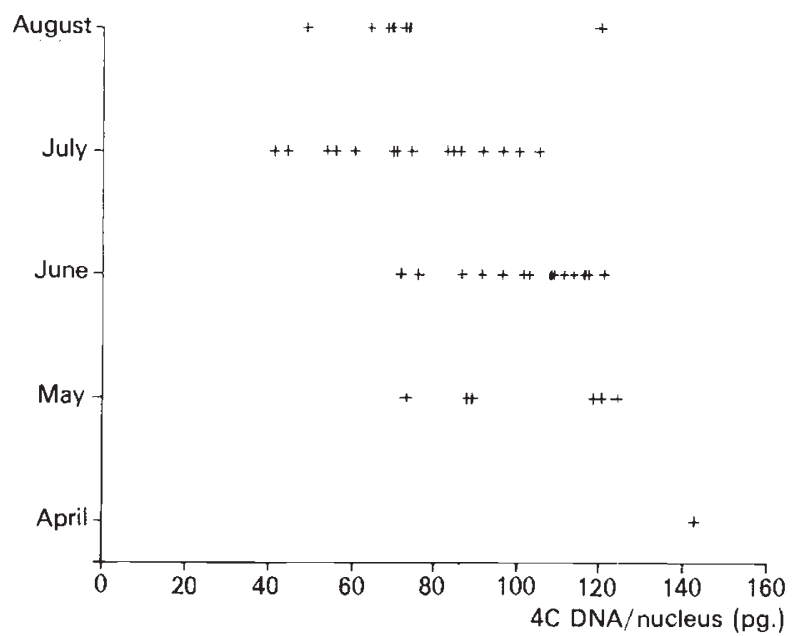

Figure 4 Relation of initial month of flowering of Allium species, determined from established plants growing in open ground at Sheffield University Experimental Garden, and mean 4C DNA values; correlation coefficient $=-0.61$ $(p<0.001 ; n=43)$. available on the flowering time of the Allium species studied. The month of initial flowering (table 1) plotted against DNA content is given in fig. 4. The correlation coefficient is highly significant $(p<0.001)$; the early flowering species have most DNA and A. ursinum, the only species to flower in April at Sheffield, has the highest DNA content. Since time of flowering is related to growth and development, this result is consistent with the suggestions of Grime and Mowforth (1982) and Grime (1983), but considerable knowledge of the natural climatic ranges of the species and their phenologies would be necessary for any further investigation.

Acknowledgements We wish to acknowledge the help and advice of Dr D. J. Goldstein in carrying out the microdensitometric measurements. One of us (R.L.) also whishes to acknowledge the financial support of the University of Al-Fatah, Libya.

\section{REFERENCES}

AL-SHEIKH HUSSAIN, L. 1977. Cytology and species relationships of Allium section Codonoprasum (Rchb.) Endl. Ph.D. Thesis, University of Sheffield.

APPELS, R., DRISCOLL, C. AND PEACOCK, W. J. 1978. Heterochromatin and highly repeated DNA sequences in rye (Secale cereale). Chromosoma (Berl.), 70, 67-89.

AYONOADU, U. W. U. 1974. Nuclear DNA variation in Phaseolus. Chromosoma (Berl.), 48, 41-49.

BADR, A. 1977. Cytology and species relationships in Allium subgenus Molium (Koch) Wendelbo. Ph.D. Thesis, University of Sheffield.

BEDBROOK, J. R., JONES, J., O'DELL, M., THOMPSON, R. AND FLAVELL, R. B. 1980. A molecular description of telomeric heterochromatin in Secale species. Cell, 19, 545-560.

BENNETT, M. D. 1972. Nuclear DNA content and minimum generation time in herbaceous plants. Proc. Roy. Soc. Lond. B., $181,109-135$.

BENNETT, M. D., GUSTAFSON, J. P. AND SMITH, J. B. 1977 Variations in nuclear DNA in the genus Secale. Chromosoma (Berl.), 61, 149-176.

BENNETT, M. D. AND SMITH, J. B. 1976. Nuclear DNA amounts in angiosperms. Phil. Trans. Roy. Soc. Lond. B., 277, 201226.

BENNETT, M. D., SMITH, J. B. AND HESLOP-HARRISON, J. S. 1982. Nuclear DNA amounts in angiosperms. Proc. Roy. Soc. Lond. B., 216, 179-199.

BÖSEN, H. AND NAGL, W. 1978. Short duration of the mitotic and endomitotic cell cycle in the heterochromatin-rich monocot Allium carinatum. Cell. Biol. int. Rep., 2, 565-571.

DEUMLiNG, B. AND GREJLHUBER, J. 1982. Characterization of heterochromatin in different species of the Scilla sibirica group (Liliaceae) by in situ hybridization of satellite DNAs and fluorochrome banding. Chromosoma (Berl.), 84, 535 555 .

EL-GADI, A. 1976. Studies on species relationships in Allium subgenus Rhizirideum (Koch) Wendelbo. Ph.D. Thesis, University of Sheffield.

EL-MAGHBUB, K. 1982. Cytology and species relationships in Allium subgenus Rhizirideum (Koch) Wendelbo. Ph.D. Thesis, University of Sheffield. 
FLAVELL, R. B. 1982. Sequence amplification, deletion and rearrangement: major sources of variation during species divergence. In Dover, G. A. and Flavell, R. B. (eds.) Genome Evolution Academic Press, London pp. 301-323.

GOLDSTEIN, D. J. 1981. Errors in microdensitometry. Histochem. J., 13, 251-267.

GRIME, J. P. 1983. Prediction of weed and crop response to climate based upon measurements of nuclear DNA content. Aspects of Applied Biology 4. Influence of environmental factors on herbicide performance and crop and weed biology, 87-98.

GRIME, J. P. AND MOWFORTH, M. A. 1982. Variation in genome size--an ecological interpretation. Nature, Lond, 299, 151153.

JOHN, B. ANI) MIKLOS, G. L. G. 1979. Functional aspects of satellite DNA and heterochromatin. Ann. Rev. Cytol., 58, $1-114$.

JONES, R. N. AND REES, H. 1968. Nuclear DNA variation in Allium. Heredity, 23, 591-605.

KENTON, A, 1983. Qualitative and quantitative chromosome change in the evolution of Gibasis. In Brandham, P. E. and Bennett, M. D. (eds.) Kew Chromosome Conference II George Allen and Unwin, pp. 273-282.

LABANI, R. 1984. Biosystematics and taxonomic relationships in the genus Allium L. Ph.D. Thesis, University of Sheffield.

L.EVAN, A. 1931. Cytological studies in Allium. I. A preliminary note. Hereditas, 15, 347-356.

LEVAN, A. 1932. Cytological studies in Allium. 1I. Chromosome morphological contribution. Hereditas, 16, 257-294.

I.Evan, A. 1933. Cytological studies in Allium. III. Allium carinatum and $A$. oleraceum. Hereditas, $18,101-114$.

LEVAN, A. 1935. Cytological studies in Allium. VI. The chromosome morphology of diploid species of Allium. Hereditas, 20, 289-330.

LEVAN, A. 1936. Die zytologie von Allium cepa $\times$ fistulosum. Hereditas, 21, 195-214.

LEVAN, A. 1937. Cytological studies in the Allium paniculatum group. Hereditas, 23, 317-370.

MURIN, A. 1976. Polyploidy and mitotic cycle. Nucleus, 19, 192-195.

NAGL, W. AND EHRENDORFER, F. 1974. DNA content, heterochromatin, mitotic index and growth in perennial and annual Anthemideae (Asteraceae) Plant Syst. Evol., 123, 35-54.

NAGL, W. AND FUSENIG, H. P. 1979. Types of chromatin organization in plant nuclei. Pl. Syst. Evol. Suppl., 2, 221233.

NARAYAN, R. K. J. 1982. Discontinuous IDNA variation in the evolution of plant species: the genus Lathyrus. Evolution, 36, 877-891.

NARAYAN, R. K. J. 1983. Chromosome change in the evolution of Lathyrus species. In Brandham, P. E. and Bennett, M. i). (eds.) Kew Chromosome Conference II, George Allen and Unwin, pp. 243-250.

PARODA, R. S. AN1) RE: I:S, H. 1971. Nuclear DNA variation in Eu-Sorghums. Chromosoma (Berl.), 32, 353-363.

PRICE, H. J. 1976. Evolution of DNA content in higher plants. Bot. Rev., 42, 27-52.
PRICE, H. J. AND BACHMANN, K. 1975. DNA content and evolution in the Microseridinae. Ann. J. Bot., 62, 262-267. RANJEKAR, P. K., PAILOTA, D. AND LAFONTAINF, J. G. 1978. Analysis of plant genomes. V. Comparative study of molecular properties of DNAs of seven Allium species. Biochem. Genet., 16, 957-970.

RAYBURN, A. I.., PRICE, H. J., SMITH, J. I). ANI) GOLD, J. R. 1985. (-band heterochromatin and DNA content in Zea mays. Amer. J. Bot., 72, 1610-1617.

REES, H., CAMHRON, F. M., HAZARIKA, M. H. ANI JONES, G. H. 1966. Nuclear variation between diploid Angiosperms. Nature, Lond, 211, 828-830.

REES, H. AND HAZARIKA, M. H. 1969. Chromosome evolution in Lathyrus. Chromosomes Today, 2, 158-165. Oliver and Boyd, Edinburgh.

RFES, H. AND JONES, R. N. 1967. Chromosome evolution in Lolium. Heredity, 22, 1-18.

REES, H. ANID JONES, R. N. 1972. The origin of the wide species variation in nuclear DNA content. Int. Rev. Cytol., 32, 53-92.

RFi:S, H. ANI) NARAYAN, R. K.J. 1981. Chromosomal DNA in higher plants. Phil. Trans. R. Soc. Lond. B, 292, 569-578.

SMITH, J. B. AND BENNETT, M. D. 1975. DNA variation in the genus Ranunculus. Heredity, 35, 231-239.

SPARROW, A. H. AND MIKSCHE, J. P. 1961. Correlation of nuclear volume and DNA content with higher plant tolerance to chronic radiation. Science, 134, 282-283.

SPARROW, A. II. AND NAUMAN, A. F. 1974. Evolutionary changes in genome and chromosome sizes and in DNA content in the grasses. Brookhaven Symp. Biol., 25, 367-389.

STEARN, W. T. 1978. European species of Allium and allied genera of Alliaceae: a synonymic enumeration. Ann. Musei Goulandris, 4. 83-198.

SteArn, W. T. 1980. Allium. In Tutin, T. G., Heywood, V. H. Burges, N. A., Moore, D. M., Valentine, D. H., Walters, S. M. and Webb, D. A. (eds.) Flora Europea, Cambridge University Press, 5, 49-69.

THOMAS, H. M. 1981. The Giemsa C-band karyotype of six Lolium species. Heredity, 46, 263-267.

VAN'T HOF, J. 1965. Relationships between mitotic cycle duration, $S$ period duration and average rate of DNA synthesis in the root meristem cells of several plants. Expl. Cell Res. $39,45-58$.

VAN'T HOF, J. AND SPARROW, A. H. 1963. A relationship between DNA content, nuclear volume and minimum mitotic cycle time. Proc. Nat. Aad. Sci., 49, 897-902.

vosA, C. G. 1976. Heterochromatic handing patterns in Allium. II. Heterochromatic variation in species of the Paniculatum group. Chromosoma (Berl.), 57, 119-133.

VVFidINSKII, A. I. 1935. Allium. In V. L. Komarov ed. Flora of the USSR. Leningrad, Academy of Sciences, USSR.

WENDELBO, P. 1969. New subgenera, sections and species of Allium. Bot. Notiser, 122, 35-37.

WENDELBO, P. 1971. Alliaceae. In Rechinger, K. H. (ed.) Flora Iranica, Akademische Druck u. Verlagsanstalt, Graz. Austria, 76

WII.L.1S, i. C. 1966. A Dictionary of Flowering Plants, 7th edn. Rev. H. K. Airy Shaw, Cambridge University Press. 